\title{
OPEN The key role of contact time in elucidating the mechanisms of enhanced decontamination by $\mathrm{Fe}^{0} / \mathrm{MnO}_{2} /$ sand systems
}

\author{
Viet $\mathrm{Cao}^{1}$, Ghinwa Alyoussef ${ }^{2}$, Nadège Gatcha-Bandjun ${ }^{3}$, Willis Gwenzi ${ }^{4}$ \&
} Chicgoua Noubactep ${ }^{2,5,6 \bowtie ~}$

Metallic iron $\left(\mathrm{Fe}^{0}\right)$ has shown outstanding performances for water decontamination and its efficiency has been improved by the presence of sand $\left(\mathrm{Fe}^{0} /\right.$ sand $)$ and manganese oxide $\left(\mathrm{Fe}^{0} / \mathrm{MnO}_{x}\right)$. In this study, a ternary $\mathrm{Fe}^{0} / \mathrm{MnO}_{x} /$ sand system is characterized for its discoloration efficiency of methylene blue (MB) in quiescent batch studies for 7, 18, 25 and 47 days. The objective was to understand the fundamental mechanisms of water treatment in $\mathrm{Fe}^{0} / \mathrm{H}_{2} \mathrm{O}$ systems using $\mathrm{MB}$ as an operational tracer of reactivity. The premise was that, in the short term, both $\mathrm{MnO}_{2}$ and sand delay $\mathrm{MB}$ discoloration by avoiding the availability of free iron corrosion products (FeCPs). Results clearly demonstrate no monotonous increase in MB discoloration with increasing contact time. As a rule, the extent of MB discoloration is influenced by the diffusive transport of $\mathrm{MB}$ from the solution to the aggregates at the bottom of the vessels (test-tubes). The presence of $\mathrm{MnO}_{x}$ and sand enabled the long-term generation of iron hydroxides for MB discoloration by adsorption and co-precipitation. Results clearly reveal the complexity of the $\mathrm{Fe}^{0} / \mathrm{MnO}_{\mathrm{x}} /$ sand system, while establishing that both $\mathrm{MnO}_{\mathrm{x}}$ and sand improve the efficiency of $\mathrm{Fe}^{0} / \mathrm{H}_{2} \mathrm{O}$ systems in the long-term. This study establishes the mechanisms of the promotion of water decontamination by amending $\mathrm{Fe}^{0}$-based systems with reactive $\mathrm{MnO}_{\mathrm{x}}$.

Since the 1950s the world is conventionally divided into two groups with regards to the access to safe drinking water: (i) developed countries striving for selecting the best available technology for water treatment, and (ii) developing countries striving for making some appropriate technologies available for their mostly low-income and rural populations $s^{1-3}$. In the meantime, cities have grown, but drinking water systems in peri-urban areas are comparable to that of rural environments without piped water ${ }^{4-6}$. Appropriate technologies are essentially considered as interim solutions wherever a centralized water supply is not yet available ${ }^{1}$. Factors relevant for selecting an appropriate solution for safe drinking water supply include ${ }^{1,7,8}$ : (i) Simplicity in operation (no special skilled personnel), (ii) robustness (no frequent break downs), (iii) affordability (low installation and operation costs), (iv) ability to function without electricity, and (v) use of local skills and readily available resources. Research during the past two decades has rediscovered filtration systems based on metallic iron $\left(\mathrm{Fe}^{0}\right)$ as an affordable, applicable, and efficient water treatment technology for decentralized water supply (e.g. households and small communities $)^{3,7,9-13}$. Such $\mathrm{Fe}^{0}$ filters are only sustainable upon admixing $\mathrm{Fe}^{0}$ with other aggregates like granular activated carbon, biochar, gravel, magnetite $\left(\mathrm{Fe}_{3} \mathrm{O}_{4}\right)$, manganese oxides $\left(\mathrm{MnO}_{\mathrm{x}}\right)$, pyrite $\left(\mathrm{FeS}_{2}\right)$, and sand ${ }^{10,14,15}$.

There are two fundamental challenges in designing $\mathrm{Fe}^{0}$ filtration systems: (i) "reactivity loss" and (ii) permeability loss ${ }^{16-20}$. Permeability loss is not addressed herein. For the presentation, it suffices to recall that this issue has been partly resolved in earlier studies demonstrating that only hybrid $\mathrm{Fe}^{0}$ filters are sustainable ${ }^{14,21}$. The remaining task is a temporal issue regarding the reaction kinetics of $\mathrm{Fe}^{0}$ corrosion, which is material-specific and has received limited attention ${ }^{22-24}$. Reactivity loss is the expression of the inherent time-dependent decrease of the

${ }^{1}$ Faculty of Natural Sciences, Hung Vuong University, Nguyen Tat Thanh Street, Viet Tri, Phu Tho 35120, Vietnam. ${ }^{2}$ Angewandte Geologie, Universität Göttingen, Goldschmidtstraße 3, 37077 Göttingen, Germany. ${ }^{3}$ Department of Chemistry, Faculty of Science, University of Maroua, BP 46, Maroua, Cameroon. ${ }^{4}$ Biosystems and Environmental Engineering Research Group, Department of Agricultural and Biosystems Engineering, University of Zimbabwe, P.O. Box MP167, Mt. Pleasant, Harare, Zimbabwe. ${ }^{5}$ Centre for Modern Indian Studies (CeMIS), Universität Göttingen, Waldweg 26, 37073 Göttingen, Germany. ${ }^{6}$ Department of Water and Environmental Science and Engineering, Nelson Mandela African Institution of Science and Technology, P.O. Box 447, Arusha, Tanzania. ${ }^{凶}$ email: cnoubac@gwdg.de 


\begin{tabular}{|c|c|c|}
\hline Aggregate & Assigned function & Comments \\
\hline $\mathrm{Fe}^{0}$ & Generates contaminant scavengers (FeCPs) & Confirmed \\
\hline $\mathrm{Fe}^{0}$ & Donates electrons to contaminants & Disproved \\
\hline GAC & Sustains iron corrosion $\left(\mathrm{Fe}^{0} / \mathrm{GAC}\right.$ cells $)$ & Questioned \\
\hline GAC & Accumulates contaminants for reduction by $\mathrm{Fe}^{0}$ & Questioned \\
\hline GAC & Sustains long-term iron corrosion & Confirmed \\
\hline Sand & Scavengers of FeCPs (in-situ coating) & Confirmed \\
\hline Sand & Impairs the efficiency of the $\mathrm{Fe}^{0}$ system & Disproved \\
\hline Sand & Sustains long-term iron corrosion & Confirmed \\
\hline $\mathrm{MnOx}$ & Corrodes $\mathrm{Fe}^{0}$ (as cathodic reaction) & Disproved \\
\hline $\mathrm{MnOx}$ & Scavengers of $\mathrm{Fe}^{2+}$ & Confirmed \\
\hline $\mathrm{MnOx}$ & Sustains long-term iron corrosion & Confirmed \\
\hline
\end{tabular}

Table 1. Summary of the operating mode of some representative aggregates relevant for hybrid $\mathrm{Fe}^{0}$ systems for water treatment. Their status according to the state-of-the-art knowledge on the $\mathrm{Fe}^{0} / \mathrm{H}_{2} \mathrm{O}$ system is given as comments. Questioned aspects have been documented in short-term laboratory experiments, but are not likely to be valid when the aggregates are coated with iron corrosion products (FeCPs).

$\mathrm{Fe}^{0}$ corrosion rate as well-documented in the corrosion literature and referred to as 'passivation'25-28. However, "reactivity loss" has been introduced in the post-1990 literature to characterize the limited electron transfer from the metal body to some dissolved contaminants ${ }^{16,19}$. Given that under natural conditions $\mathrm{Fe}^{0}$ is corroded only by protons from water dissociation (Eq. 1) ${ }^{29}$, Miyajima and Noubactep ${ }^{30}$ argued that reactivity loss is a mirage. In fact, "reactivity loss" has also occurred in $\mathrm{Fe}^{0}$-based permeable reactive barriers successfully working for up to two decades ${ }^{31-34}$. On the other hand, Roh et al. ${ }^{35}$ reported on $\mathrm{Fe}^{0}$ specimens from World War I still corroding in soils. Clearly, it can be argued that the old motto "rust never rests" is valid for $\mathrm{Fe}^{0}$ filters where corrosion additionally occurs under immersed conditions. The question is, how to ensure that $\mathrm{Fe}^{0}$ oxidation with changing corrosion rates still secures clean water in the long-term?

$$
\begin{gathered}
\mathrm{Fe}^{0}+2 \mathrm{H}^{+} \Rightarrow \mathrm{Fe}^{2+}+\mathrm{H}_{2} \\
\mathrm{Fe}^{0}+\mathrm{MnO}_{2}+4 \mathrm{H}^{+} \Rightarrow \mathrm{Mn}^{2+}+\mathrm{Fe}^{2+}+2 \mathrm{H}_{2} \mathrm{O} \\
2 \mathrm{Fe}^{2+}+\mathrm{MnO}_{2}+4 \mathrm{H}^{+} \Rightarrow \mathrm{Mn}^{2+}+2 \mathrm{Fe}^{3+}+2 \mathrm{H}_{2} \mathrm{O} \\
2 \mathrm{Fe}^{2+}+\mathrm{MnO}_{2}+2 \mathrm{H}_{2} \mathrm{O} \Rightarrow \mathrm{Mn}^{2+}+2 \mathrm{FeOOH}+2 \mathrm{H}^{+}
\end{gathered}
$$

During the past decade, substantial experiences have been accumulated on increasing the efficiency of $\mathrm{Fe}^{0}$ \% $\mathrm{H}_{2} \mathrm{O}$ systems by admixing $\mathrm{Fe}^{0}$ with other materials (Table 1$)^{15,36}$. However, these efforts were mostly misled by the misconception that $\mathrm{Fe}^{0}$ is a reducing agent ${ }^{36}$. Fortunately, available data can be re-interpreted based on the chemistry of the system. It suffices to consider that reduction is not a relevant contaminant removal mechanism, and that contaminant reduction is never mediated by electrons from the metal body ${ }^{11}$. For example, $\mathrm{MnO}_{2}$ is not reduced by $\mathrm{Fe}^{0}$ (Eq. 2), but rather by $\mathrm{Fe}^{2+}$ (Eq. 3a) (Fig. 1). Equation 3b depicts that $\mathrm{MnO}_{2}$ reductive dissolution by $\mathrm{Fe}^{2+}$ induces acidification of the system (releases protons). $\mathrm{O}_{2}$ and other dissolved species are equally reduced by $\mathrm{Fe}^{2+}$ and other reductive species present in the $\mathrm{Fe}^{0} / \mathrm{H}_{2} \mathrm{O}$ system (e.g., $\mathrm{H}_{2}, \mathrm{Fe}_{3} \mathrm{O}_{4}$, green rust) ${ }^{37-40}$. Thus, it is established that contaminants are reduced by an indirect mechanism (Fig. 1), and that this process continues even after virtual surface passivation (which is thus not a "loss of their reactivity"). Successful efforts to overcome $\mathrm{Fe}^{0}$ passivation include the addition of gravel ${ }^{41,42}$, magnetite ${ }^{15,43}, \mathrm{MnO}_{\mathrm{x}}^{44,45}$, pyrite ${ }^{36,46}$, and sand ${ }^{47,48}$.

The presence of inert sand improves the efficiency of even batch $\mathrm{Fe}^{0} / \mathrm{H}_{2} \mathrm{O}$ systems for water treatment ${ }^{49}$. However, the studies testing other reactive materials have not considered inert systems (e.g., sand) as operational references. Only Ndé-Tchoupé et al. ${ }^{50}$ did such a comparison. However, the objective was to test pozzolan as an alternative filling material to sand for $\mathrm{Fe}^{0}$ filters. In other words, while testing magnetite $\left(\mathrm{Fe}_{3} \mathrm{O}_{4}\right)$ as admixing agent for the reductive transformation of contaminants ${ }^{43}$, a reference $\mathrm{Fe}^{0} /$ sand should have been considered in parallel experiments. The inclusion of an operational reference enables a better understanding of the specific action of the reactive additive (here $\mathrm{Fe}_{3} \mathrm{O}_{4}$ ). Following the science of aqueous iron corrosion under environmental conditions $s^{25,28}$, this study premises that iron passivation is delayed by avoiding the precipitation of iron corrosion products in the vicinity of the metal. Thus, $\mathrm{Fe}^{2+}$ and $\mathrm{Fe}^{3+}$ ions are consumed instead of coating sand in $\mathrm{Fe}^{0} / \mathrm{sand}$ systems, and $\mathrm{Fe}^{2+}$ ions are additionally consumed in the reductive dissolution of $\mathrm{MnO}_{\mathrm{x}}$ (Eq. 2) in the $\mathrm{Fe}^{0} / \mathrm{MnO}_{\mathrm{x}} /$ sand systems (Fig. 1). Note that all other aggregates including $\mathrm{Fe}_{3} \mathrm{O}_{4}$ and granular activated carbon are in-situ coated by FeCPs like sand and the postulated effects are not realizable in the long-term (Table 1).

$\mathrm{Fe}^{0}$ is used to efficiently remove various contaminants such as turbidity, pathogens, and dissolved species from aqueous solutions ${ }^{51-60}$. Chemical pollutants in the aqueous phase can be ions, molecules, and colloids. For reducible dissolved species, there is a trend to consider $\mathrm{Fe}^{0}$-based materials $\left(\mathrm{E}^{0}=-0.44 \mathrm{~V}\right.$ ) as (strong) reducing agent ${ }^{51,56,60}$, and contaminant reductive transformation as an electrochemical process ${ }^{58}$. It is evident that colloids, 


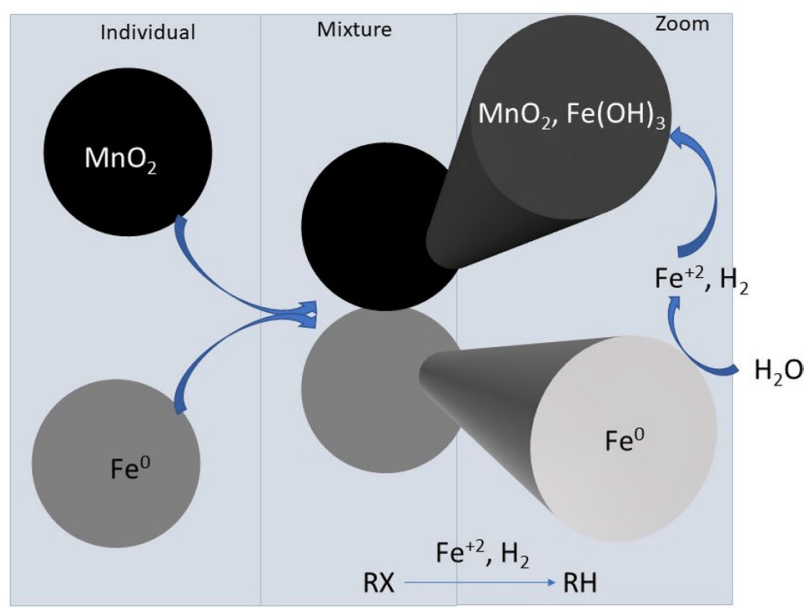

Figure 1. Scheme showing the pathways of contaminant reductive transformations in $\mathrm{Fe}^{0} / \mathrm{MnO}_{2} / \mathrm{H}_{2} \mathrm{O}$ systems. Only water has access to the metal surface. $\mathrm{Fe}^{2+}$ and $\mathrm{H}_{2}$ are stand-alone reducing agents. $\mathrm{MnO}_{2}$ and other relevant dissolved species (e.g. $\mathrm{RX}$ ) are reduced by $\mathrm{Fe}^{2+}$ and $\mathrm{H}_{2}$. Upon the oxidation of $\mathrm{Fe}^{2+}$, various solid iron hydroxides/oxides (e.g. $\mathrm{Fe}(\mathrm{OH})_{3}$ ) precipitate and act as contaminant scavengers. RX stands for an halogenated hydrocarbon. The key information is that $\mathrm{MnO}_{2}$ is not reduced by $\mathrm{Fe}^{0}$.

\begin{tabular}{|c|c|c|c|c|}
\hline System & $\mathrm{Fe}^{0}$ & $\mathrm{MnO}_{2}$ & Sand & $\mathrm{Fe}^{0} / \mathrm{MnO}_{2} /$ Sand \\
\hline $\mathrm{t}_{0}=0$ & $\mathrm{Fe}^{0}$ & $\mathrm{MnO}_{2}$ & Sand & $\mathrm{Fe}^{0}+\mathrm{MnO}_{2}+\mathrm{Sand}$ \\
\hline$t>t_{o}$ & $\mathrm{Fe}^{0}+\mathrm{FeCPs}$ & $\mathrm{MnO}_{2}+\mathrm{MnOOH}$ & Sand & $\mathrm{Fe}^{0}+\mathrm{MnO}_{2}+\mathrm{Sand}+\mathrm{FeCPs}+\mathrm{MnOOH}$ \\
\hline $\mathrm{t}_{\infty}$ & $\mathrm{FeCPs}$ & $\mathrm{MnOOH}$ & Sand & $\mathrm{MnOOH}+\mathrm{Sand}+\mathrm{FeCPs}$ \\
\hline
\end{tabular}

Table 2. Time-dependent inventory of reactive species in the four investigated systems. $t_{0}$ corresponds to the start of the experiment, while $\mathrm{t}_{\infty}$ corresponds to the time required for $\mathrm{Fe}^{0}$ depletion. It is assumed that $\mathrm{MnO}_{2}$ is quantitatively converted to $\mathrm{MnOOH}$ without impact on $\mathrm{MB}$ discoloration. FeCPs: Fe corrosion products. FeCPs can be free or coated on sand. (Adapted from ref. ${ }^{70}$ ).

pathogens, and suspended solids (turbidity) are not removed by any chemical reaction. Rather, they are removed via coagulation and co-precipitation. The previous text has already demonstrated that no electrochemical contaminant reduction is possible in a $\mathrm{Fe}^{0} / \mathrm{H}_{2} \mathrm{O}$ system ${ }^{58}$. Yet, published results using the $\mathrm{Fe}^{0} / \mathrm{MnO}_{2}$ mixtures are mainly premised on the wrong assumption that contaminant removal occurs via reduction by electrons from $\mathrm{Fe}^{0}$ (Fig. 1) (Table 1) ${ }^{6,54,57}$. Accordingly, there is still a need to further clarify the role of $\mathrm{MnO}_{2}$ in sustaining the efficiency of $\mathrm{Fe}^{0} / \mathrm{H}_{2} \mathrm{O}$ systems for water treatment ${ }^{59}$. In particular, there is need to elucidate how insoluble $\mathrm{Fe}(\mathrm{OH})_{3}$ contribute to the co-precipitation of pollutants from the aqueous phase.

The objective of this study is to investigate the impact of $\mathrm{MnO}_{\mathrm{x}}$ addition on the efficiency of $\mathrm{Fe}^{0} / \mathrm{H}_{2} \mathrm{O}$ systems for MB discoloration as a function of the experimental duration (contact time). The specific objective is to confirm the suitability of 'MB discoloration' as powerful tool for the characterization of decontaminantion processes in $\mathrm{Fe}^{0} / \mathrm{H}_{2} \mathrm{O}$ systems while using $\mathrm{MnO}_{\mathrm{x}}$ and sand to control the availability of 'free' FeCPs. The extent of MB discoloration is investigated in five different systems: (i) $\mathrm{Fe}^{0}$ alone, (ii) sand alone, (iii) $\mathrm{Fe}^{0} / \mathrm{sand}$, (iv) $\mathrm{Fe}^{0} /$ $\mathrm{MnO}_{\mathrm{x}}$, and (v) $\mathrm{Fe}^{0} / \mathrm{MnO}_{\mathrm{x}} /$ sand for 7, 18, 25 and 47 days. A comparison of the results from the five systems provides critical information on the contaminant removal mechanisms and the role of $\mathrm{MnO}_{\mathrm{x}}$.

\section{Materials and methods}

The theory of iron and manganese cycle in a $\mathrm{Fe}^{0} / \mathrm{MnO}_{\mathbf{x}} /$ sand system. Initially $\left(\mathrm{t}_{0}=0\right)$, when $\mathrm{Fe}^{0}$, $\mathrm{MnO}_{\mathrm{x}}$ and sand are put into the solution, there is no dissolved iron and no dissolved manganese in the system (Table 2). At $\mathrm{t}>\mathrm{t}_{0}, \mathrm{Fe}^{0}$ is dissolved by protons (water) to generate $\mathrm{H}_{2}$ and $\mathrm{Fe}^{2+}$ (Eq. 1). $\mathrm{Fe}^{2+}$ induces the reductive dissolution of $\mathrm{MnO}_{\mathrm{x}}$ (Eq. 3) ${ }^{61-65}$. At $\mathrm{t}>\mathrm{t}_{0}$, the $\mathrm{Fe}^{0} / \mathrm{MnO}_{\mathrm{x}} /$ sand system hosts dynamic processes which might continue after $\mathrm{Fe}^{0}$ depletion. In fact, the mixture of $\mathrm{Fe}$ and $\mathrm{MnO}_{\mathrm{x}}$ minerals is a very complex reactive system that has been investigated for more that a century ${ }^{6-68}$. The uniqueness of the $\mathrm{Fe}^{0} / \mathrm{MnO}_{\mathrm{x}} /$ sand system is that Fe minerals are generated in-situ and are comparatively more reactive than aged minerals like goethite or hematite. Because the $\mathrm{pH}$ of the system is larger than 5.0, in the absence of ligands, Fe and Mn hydroxides have very low solubility and precipitate not far away from their points of nucleation ${ }^{65,69}$. The dynamics within the $\mathrm{Fe}^{0} / \mathrm{MnO}_{\mathrm{x}} /$ sand entail a series of interchanges of iron and manganese from older to younger forms as follows: (i) dissolution of $\mathrm{Fe}^{0}$ and $\mathrm{MnO}_{\mathrm{x}}$, (ii) migration of $\mathrm{Fe}^{2+}, \mathrm{Fe}^{3+}$ and $\mathrm{Mn}^{2+}$ from the areas of their generation to areas where precipitation will occur, and (iii) precipitation in one or more forms of iron and manganese hydroxide.

In the $\mathrm{Fe}^{0} / \mathrm{MnO}_{\mathrm{x}} /$ sand system, iron and manganese chemically precipitate at the surface of $\mathrm{MnO}_{\mathrm{x}}$, sand or in the bulk solution. Due to the good adsorptive affinities of $\mathrm{Fe}^{2+}$ and $\mathrm{Fe}^{3+}$ for sand surface, it is assumed that 


\begin{tabular}{|l|l|l|l|l|l|}
\hline System & $\mathrm{Fe}^{0}\left(\mathrm{~g} \mathrm{~L}^{-1}\right)$ & Sand $\left(\mathrm{g} \mathrm{L}^{-1}\right)$ & $\mathrm{MnO}_{2}\left(\mathrm{~g} \mathrm{~L}^{-1}\right)$ & Materials & Comments \\
\hline Reference & 0.0 & 0.0 & 0.0 & None & Blank experiment \\
\hline System 1 & 4.5 & 0.0 & 0.0 & $\mathrm{Fe}^{0}$ alone & Blank for $\mathrm{Fe}^{0}$ \\
\hline System 2 & 0.0 & 45.0 & 0.0 & sand alone & Blank for sand \\
\hline System 3 & 0.0 & 0.0 & 2.3 & $\mathrm{MnO}_{2}$ alone & Blank for $\mathrm{MnO}_{2}$ \\
\hline System 4 & 4.5 & 45.0 & 0.0 & $\mathrm{Fe}^{0} /$ sand & Reference system \\
\hline System 5 & 4.5 & 0.0 & 4.5 & $\mathrm{Fe}^{0} / \mathrm{MnO}_{2}$ & Reference system \\
\hline System 6 & 4.5 to 45 & 45.0 & 4.5 & $\mathrm{Fe}^{0} /$ sand $/ \mathrm{MnO}_{2}$ & $\mathrm{Fe}^{0}$ loading as variable \\
\hline
\end{tabular}

Table 3. Overview on the six (6) investigated systems. The material loadings correspond to Fig. 2.

the deposition of Fe hydroxides at its surface (coating) will compete with $\mathrm{Fe}^{2+}$ consumption by the reductive dissolution of $\mathrm{MnO}_{\mathrm{x}}$ until sand coating is completed. Thereafter, the "free" precipitation of iron and manganese occurs and the final products are deposits of more or less pure iron and manganese ores ${ }^{66,71}$. In other words, the investigated $\mathrm{Fe}^{0} / \mathrm{MnO}_{\mathrm{x}} /$ sand system is a ternary system only at the start of the experiment. It then turns to a mixture of $\mathrm{Fe}^{0}$, iron oxide-coated sand, iron oxide-coated $\mathrm{MnO}_{\mathrm{x}}, \mathrm{Fe} / \mathrm{Mn}$ shales, etc. Even after $\mathrm{Fe}^{0}$ depletion, the $\mathrm{Fe} / \mathrm{Mn}$ mineral mixture will still be a reactive one, with a great potential for water treatment by both abiotic and biotic processes ${ }^{67,68,72}$.

Experimental details. This experimental section is adapted from Cao et al. ${ }^{70}$ using the same experimental design and two more $\mathrm{MnO}_{2}$ minerals.

Solutions. The used methylene blue (MB-Basic Blue 9 from Merck) was of analytical grade. The working solution was $10.0 \mathrm{mg} \mathrm{L}^{-1}$ prepared by diluting a $1000 \mathrm{mg} \mathrm{L}^{-1}$ stock solution. The stock solution was prepared by dissolving accurately weighted $\mathrm{MB}$ in tap water. The use of tap water rather than deionised water was motivated by the fact that tap water is closer to natural water in its chemical composition. The MB molecular formula is $\mathrm{C}_{16} \mathrm{H}_{18} \mathrm{~N}_{3} \mathrm{SCl}$ corresponding to a molecular weight of $319.85 \mathrm{~g}$. MB was chosen in this study because of its wellknown strong adsorption onto solids ${ }^{70}$.

Solid materials. Metallic iron $\left(\mathrm{Fe}^{0}\right)$. The used $\mathrm{Fe}^{0}$ material was purchased from iPutech (Rheinfelden, Germany). The material is available as filings with a particle size between 0.3 and $2.0 \mathrm{~mm}$. Its elemental composition as specified by the supplier was: C: $3.52 \%$; $\mathrm{Si}: 2.12 \%$; $\mathrm{Mn}: 0.93 \%$; $\mathrm{Cr}: 0.66 \%$ while the balance was Fe. The material was used without any further pre-treatment. $\mathrm{Fe}^{0}$ was proven as a powerful discoloration agent for $\mathrm{MB}$ given that discoloration agents in the form of FeCPs are progressively generated in-situ ${ }^{70}$.

Manganese dioxide $\left(\mathrm{MnO}_{2}\right)$. The tested natural $\mathrm{MnO}_{2}$-bearing minerals was Manganit from Ilfeld/Harz, Thüringen (Germany). The mineral was crushed and fractionated by sieving. The fraction $0.5-1.0 \mathrm{~mm}$ was used without any further pre-treatment. No chemical, mineralogical nor structural characterizations were performed. $\mathrm{MnO}_{2}$ is a reactive mineral ${ }^{73-75}$ and is used to delay the availability of 'free' iron corrosion products (FeCPs) in the system. This results in a delay of quantitative MB discoloration ${ }^{30}$.

Sand. The used sand was a commercial material for aviculture ("Papagaiensand" from RUT-Lehrte/Germany). The sand was used as received without any further pre-treatment. The particle size was between 2.0 and $4.0 \mathrm{~mm}$. Sand was used as an adsorbent because of its worldwide availability and its use as admixing agent in $\mathrm{Fe}^{0}$ barriers $^{50,76}$. The adsorption capacity of sand for MB has been systematically documented as early as in 1955 by Mitchell et al. ${ }^{77}$.

$M B$ discoloration. Quiescent batch experiments (non-shaken) were conducted in assay tubes for experimental durations of $7,18,25$ and $47 \mathrm{~d}$. The batches consisted of 0.0 or $1.0 \mathrm{~g}$ of sand, 0.0 or $0.1 \mathrm{~g}$ to Fe $\mathrm{Fe}^{0}, 0.0$ or $0.05 \mathrm{~g}$ of $\mathrm{MnO}_{2}$ and mixtures thereof in $22.0 \mathrm{~mL}$ of a $10.0 \mathrm{mg} \mathrm{L}^{-1} \mathrm{MB}$ solution. The investigated systems were: (i) $\mathrm{Fe}^{0}$ alone, (ii) sand alone, (iii) $\mathrm{MnO}_{2}$ alone, (iv) $\mathrm{Fe}^{0} /$ sand, (v) $\mathrm{Fe}^{0} / \mathrm{MnO}_{2}$ and (vi) $\mathrm{Fe}^{0} /$ sand $/ \mathrm{MnO}_{2}$. The efficiency of individual systems at discolouring $\mathrm{MB}$ was characterized at laboratory temperature (about $22^{\circ} \mathrm{C}$ ). Initial $\mathrm{pH}$ was about 8.2. After equilibration, up to $3.0 \mathrm{~mL}$ of the supernatant solutions were carefully retrieved (no filtration) for $\mathrm{MB}$ measurements (no dilution). Each experiment was performed in triplicates, and averaged values are presented. Table 3 summarizes the aggregate content of the $6 \mathrm{Fe}^{0} / \mathrm{MnO}_{2} /$ sand systems investigated herein. The operational reference (blank experiment) is also added. Note that the pure $\mathrm{Fe}^{0}$ system ( $\mathrm{Fe}^{0}$ alone) is regarded as a ' $\mathrm{Fe}^{0} / \mathrm{MnO}_{2} /$ sand system' without $\mathrm{MnO}_{2}$ nor sand.

Analytical methods. Iron and MB aqueous concentrations were determined by a Cary 50 UV-Vis spectrophotometer (Varian). The working wavelengths for MB and iron were 664.5 and $510.0 \mathrm{~nm}$, respectively. Cuvettes with $1.0 \mathrm{~cm}$ light path were used. The spectrophotometer was calibrated for Fe and $\mathrm{MB}$ concentrations $\leq 10.0 \mathrm{mg}$ $\mathrm{L}^{-1}$. The $\mathrm{pH}$ value was measured by combined glass electrodes (WTW Co., Germany). 

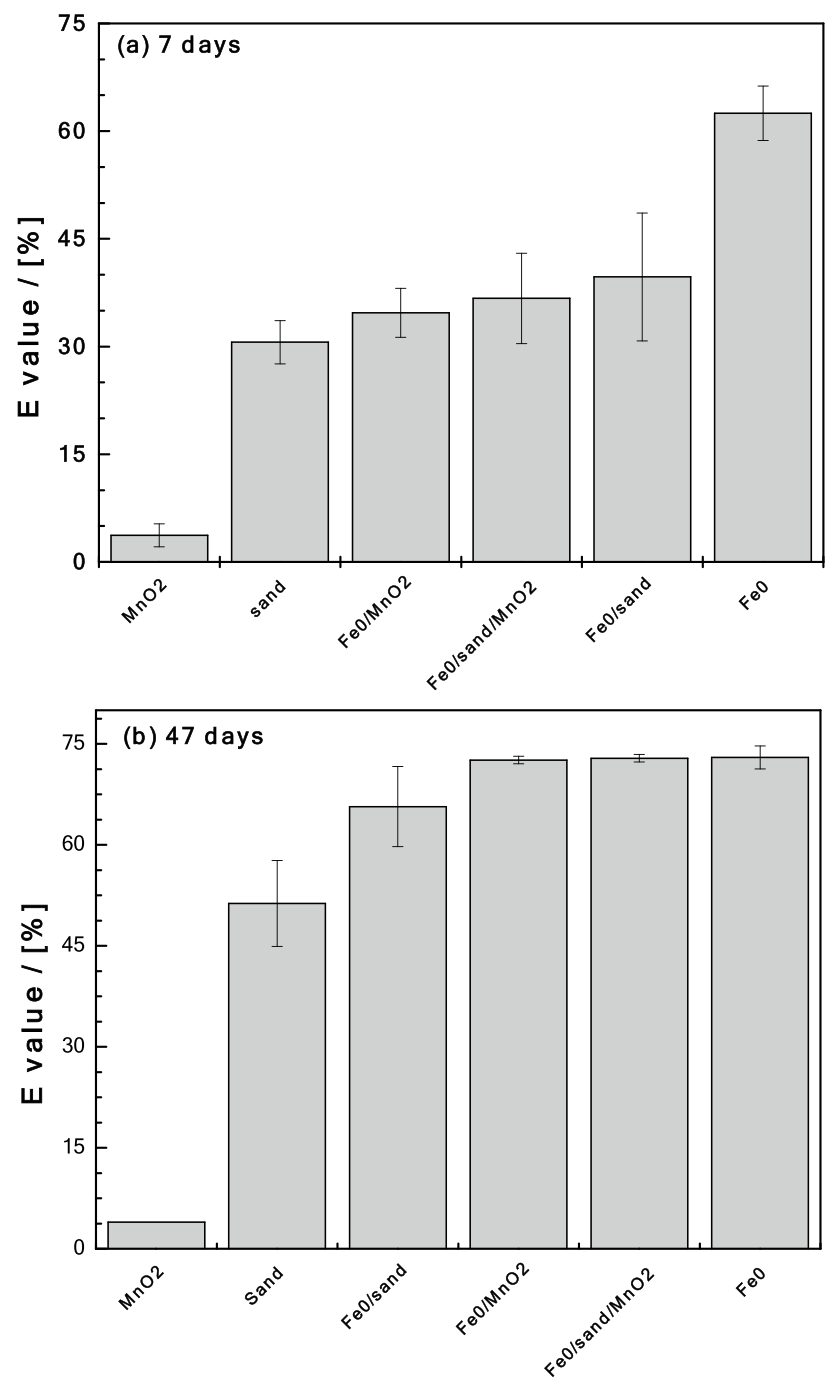

Figure 2. Comparison of the efficiency of tested materials for methylene blue (MB) discoloration for 7 (a) and 47 days (b). Experimental conditions: $\left[\mathrm{Fe}^{0}\right]=0$ to $45 \mathrm{~g} \mathrm{~L}^{-1}$; [sand] $=45 \mathrm{~g} \mathrm{~L}^{-1}$; and $\left[\mathrm{MnO}_{2}\right]=2.3 \mathrm{~g} \mathrm{~L}^{-1}$.

Expression of $M B$ discoloration results (E value). In order to characterize the magnitude of the tested systems for $\mathrm{MB}$ discoloration, the discoloration efficiency (E) was calculated (Eq. 4). After the determination of the residual $\mathrm{MB}$ concentration $(\mathrm{C})$, the corresponding percent $\mathrm{MB}$ discoloration (E value) was calculated as:

$$
\mathrm{E}=\left[1-\left(\mathrm{C} / \mathrm{C}_{0}\right)\right] \times 100 \%,
$$

where, $\mathrm{C}_{0}$ is the initial aqueous $\mathrm{MB}$ concentration (ideally $10.0 \mathrm{mg} \mathrm{L}^{-1}$ ), while $\mathrm{C}$ gives the $\mathrm{MB}$ concentration after the experiment. The operational initial concentration $\left(\mathrm{C}_{0}\right)$ for each case was acquired from a triplicate control experiment without additive material (so-called blank). This procedure was to account for experimental errors during dilution of the stock solution, MB adsorption onto the walls of the reaction vessels, and all other possible side reactions during the experiments.

\section{Results and discussion}

Evidence for the complexity of the $\mathrm{Fe}^{0} / \mathrm{MnO}_{2} /$ sand systems. Figure 2 compares the extent of $\mathrm{MB}$ discoloration in the six investigated systems for 7 and 47 days. Figure 2a clearly shows that, after $7 \mathrm{~d}$, only $\mathrm{MnO}_{2}$ had not significantly discolored $\mathrm{MB}(4 \%)$ while $\mathrm{Fe}^{0}$ alone depicts the best discoloration efficiency $(62 \%)$. The $\mathrm{E}$ values for the other systems varied between 31 and $40 \%$. The increasing order of efficiency was: $\mathrm{MnO}_{2}<$ sand $<\mathrm{Fe}^{0} / \mathrm{MnO}_{2}<\mathrm{Fe}^{0} / \mathrm{MnO}_{2} / \mathrm{sand}<\mathrm{Fe}^{0} /$ sand $<\mathrm{Fe}^{0}$. These results can be regarded as counter-intuitive since binary $\left(\mathrm{Fe}^{0} / \mathrm{MnO}_{2}, \mathrm{Fe}^{0} /\right.$ sand $)$ and ternary $\left(\mathrm{Fe}^{0} / \mathrm{MnO}_{2} /\right.$ sand $)$ performed less than $\mathrm{Fe}^{0}$ alone. In conventional shaken or stirred batch experiments, involved processes are accelerated to the extent that achieved results are the intuitive ones observed after 47 days (Fig. 2 b) ${ }^{78}$.

Figure $2 \mathrm{~b}$ compares the extent of $\mathrm{MB}$ discoloration in the six systems after 47 days. Compared to the results after 7 days, the extent of $\mathrm{MB}$ discoloration has increased to more than $50 \%$ in all systems, except $\mathrm{MnO}_{2}$ alone. Based on the absolute $\mathrm{E}$ values, the increasing order of efficiency was: $\mathrm{MnO}_{2}(4 \%)<$ sand $(51 \%)<\mathrm{Fe}^{0} / \mathrm{sand}$ 

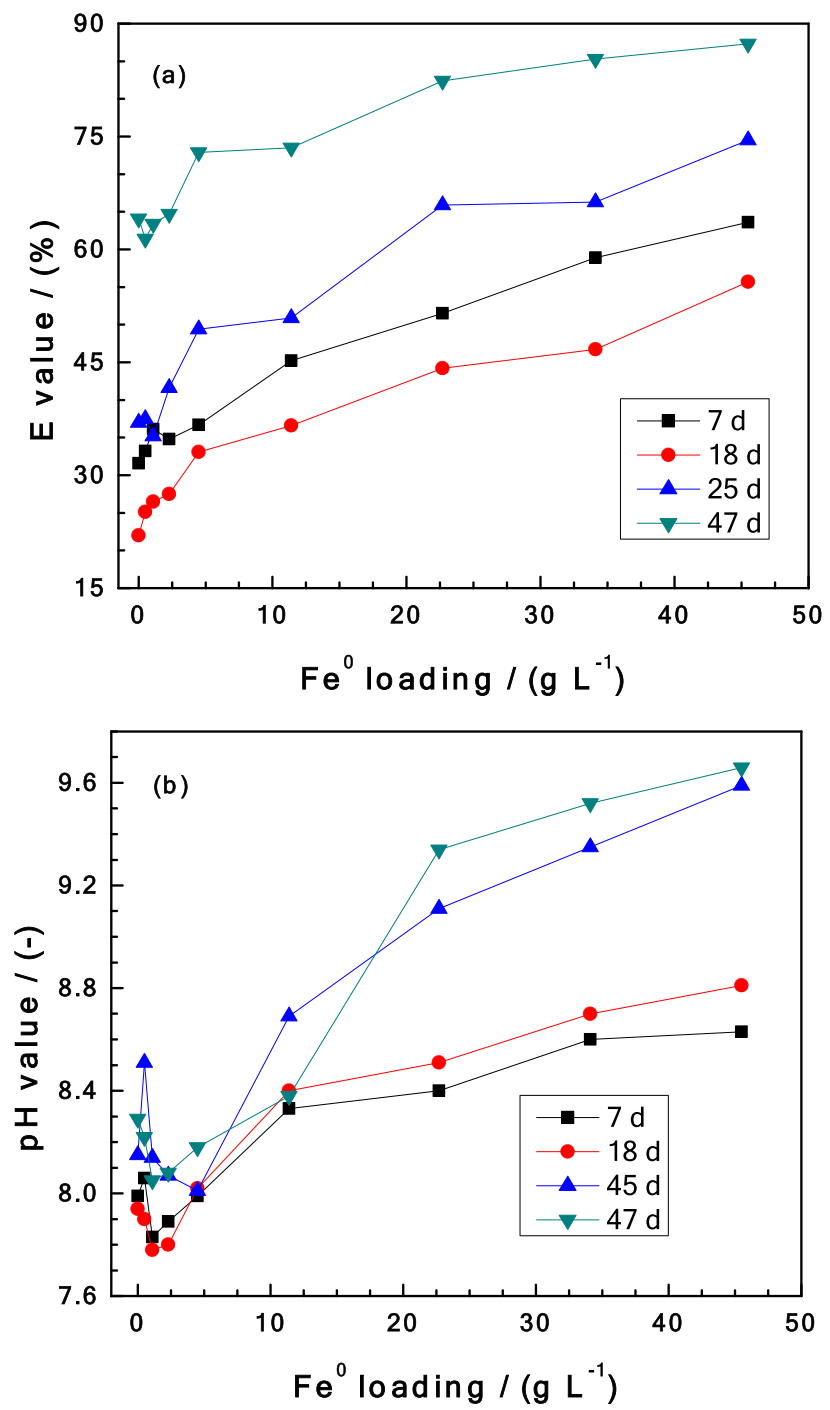

Figure 3. Changes in $\mathrm{Fe}^{0} / \mathrm{sand} / \mathrm{MnO}_{2}$ systems as impacted by the addition of various $\mathrm{Fe}^{0}$ loading for $7,18,25$ and 47 days: (a) Methylene blue discoloration, and (b) $\mathrm{pH}$ value. Experimental conditions: $\left[\mathrm{Fe}^{0}\right]=2.3$ to $45 \mathrm{~g}$ $\mathrm{L}^{-1}$; [sand] $=22.5 \mathrm{~g} \mathrm{~L}^{-1}$; and $\left[\mathrm{MnO}_{2}\right]=2.3 \mathrm{~g} \mathrm{~L}^{-1}$. The lines are not fitting functions, they simply connect points to facilitate visualization.

$(66 \%)<\mathrm{Fe}^{0} / \mathrm{MnO}_{2}=\mathrm{Fe}^{0} / \mathrm{MnO}_{2} / \mathrm{sand}=\mathrm{Fe}^{0}(72 \%)$. It is interesting to note that $\mathrm{Fe}^{0} /$ sand performed less than $\mathrm{Fe}^{0}$ alone and the two $\mathrm{MnO}_{2}$-bearing systems. This observation alone confirms that $\mathrm{MnO}_{2}$-amendment enhances the efficiency of $\mathrm{Fe}^{0} / \mathrm{H}_{2} \mathrm{O}$ systems by "reinforcing" corrosion (Eq. 3), but only in the long-term. Thus, the complexity of the ternary system as well as the need to understand its operation model is apparent. This is achieved herein by investigating the systems for 7, 18, 25 and 47 days. This corresponds to following the fate of aqueous MB (discoloration) as the contact time increases from 7 to 47 days ${ }^{59,70,71}$. In particular the variation of the $\mathrm{pH}$ value in the systems will be discussed in detail.

Effect of the contact time on the $\mathrm{Fe}^{0} / \mathrm{MnO}_{2} /$ sand system. Figure 3 a compares the extent of $\mathrm{MB}$ discoloration in $\mathrm{Fe}^{0} / \mathrm{MnO}_{2}$ /sand systems for the four tested contact times $(7,18,25$ and $47 \mathrm{~d})$ and Fig. $3 \mathrm{~b}$ depicts the corresponding changes in $\mathrm{pH}$ values. It is seen that the lowest extent of $\mathrm{MB}$ discoloration corresponds to $18 \mathrm{~d}$ contact time. This means that after 7 days the system performed better than after $18 \mathrm{~d}$. The observation can be regarded as counter-intuitive, while the monotonous increase of the $\mathrm{pH}$ value (Fig. $3 \mathrm{~b}$ ) is intuitive. The investigated systems were $0 \leq\left[\mathrm{Fe}^{0}\right]\left(\mathrm{g} \mathrm{L}^{-1}\right) \leq 45$, with $\left[\mathrm{MnO}_{2}\right]=2.3 \mathrm{~g} \mathrm{~L}^{-1}$ and $[$ sand $]=45 \mathrm{~g} \mathrm{~L}^{-1}$. This means that $\left[\mathrm{Fe}^{0}\right]=0.0 \mathrm{~g} \mathrm{~L}^{-1}$ corresponds to a $\mathrm{MnO}_{2} /$ sand system or simplified to the sand system as $\mathrm{MnO}_{2}$ has no adsorptive affinities for $\mathrm{MB}$ (Fig. 2). In other words, the counter-intuitive observation corresponds to the effect of $\mathrm{MnO}_{2}$ on the $\mathrm{Fe}^{0} / \mathrm{H}_{2} \mathrm{O}$ system.

A key feature from Fig. $3 \mathrm{a}$ is that there is an intuitive monotonous increase of the Evalue with increasing $\mathrm{Fe}^{0}$ loading for all four tested contact times. This suggests that if the experiments were performed by different investigators, the given interpretations would have been conclusive and even convincing. The tested experimental conditions were selected based on past works ${ }^{30,79}$ to achieved such results. In addition, most of the observations 
made by researchers in $\mathrm{Fe}^{0} / \mathrm{H}_{2} \mathrm{O}$ systems are just static snap-shots (mostly inaccurately measured) of processes occurring over an enormous range of time scales ${ }^{80}$. Following this premise, it was necessary to further vary the experimental conditions to maximize the chance to make more relevant observation ${ }^{81}$. One really intriguing observation is that the $\mathrm{MB}$ previously removed ( $\mathrm{t}<7$ days) was released back to the solution at day 18 such that MB discoloration was lower even in the sand system (Fig. 3a).

This $\mathrm{MB}$ desorption is rationalized by the $\mathrm{pH}$ decrease accompanying $\mathrm{MnO}_{2}$ reductive precipitation as given in Eq. (3b). By decreasing the $\mathrm{pH}$ value, further adsorption onto sand is inhibited and the previously adsorbed $\mathrm{MB}$ is desorbed and released into solution (Fig. 3a). On the other hand, the process of $\mathrm{Fe}^{0}$ dissolution by $\mathrm{MnO}_{2}$ implies intensified interactions at the bottom of the assay tubes which slowed down the diffusion of MB from the bulk solution. Iron corrosion determined the extent of MB discoloration and the intuitive increase of MB discoloration with increasing $\mathrm{Fe}^{0}$ loading is observed in all systems only after a pseudo-steady state is established in the systems or the capacity of $\mathrm{MnO}_{2}$ is exhausted. Alyoussef ${ }^{59,70,71}$ tested a parallel system with $4.5 \mathrm{~g} \mathrm{~L}^{-1}$ of $\mathrm{MnO}_{2}$ and observed a larger decrease of $\mathrm{MB}$ discoloration for 18 days. Similar observations were made by Noubactep et al. ${ }^{82}$ in their experiments for uranium removal.

Figure $3 \mathrm{~b}$ shows that for $\left[\mathrm{Fe}^{0}\right]>7.5 \mathrm{~g} \mathrm{~L}^{-1}$, the $\mathrm{pH}$ value monotonously increases with increasing $\mathrm{Fe}^{0}$ loading. For $\left[\mathrm{Fe}^{0}\right]<7.5 \mathrm{~g} \mathrm{~L}^{-1}$, there were some fluctuations justified by the co-occurrence of $\mathrm{Fe}^{0}$ corrosion (consuming protons-Eq. 1) and $\mathrm{MnO}_{2}$ reductive dissolution (producing protons-Eq. 3b) to fix the $\mathrm{pH}$ of the systems. Again, once the oxidation capacity of $\mathrm{MnO}_{2}$ is exhausted, iron corrosion controls the $\mathrm{pH}$ of the system.

The comparative evaluation of the time-dependent changes of $\mathrm{E}$ and $\mathrm{pH}$ values has clarified the operating mode of $\mathrm{MnO}_{2}$ in enhancing the efficiency of the $\mathrm{Fe}^{0} / \mathrm{H}_{2} \mathrm{O}$ system without any solid phase characterization. This discussion has equally not considered the redox reactivity of $\mathrm{MnO}_{2}$ for $\mathrm{Fe}^{0}$ (and $\mathrm{MB}$ ). Only the availability of "free" FeCPs was considered in the investigated single, binary and ternary aggregate systems. Achieved results corroborate the usefulness of varying several operational parameters to better understand complex dynamic systems $^{81,83,84}$.

Significance of the findings. Operating mode of remediation $\mathrm{Fe}^{0} / \mathrm{H}_{2} \mathrm{O}$ systems. This study has confirmed that $\mathrm{Fe}^{0}$ in engineered filtration systems is oxidized by protons to ferrous ion $\left(\mathrm{Fe}^{2+}\right)$ (Eq. 1). $\mathrm{Fe}^{2+}$ ions are partly transferred to the surface of available aggregates (e.g. $\mathrm{MnO}_{2}$ and sand) and is oxidized further to ferric ion $\left(\mathrm{Fe}^{3+}\right)$ and deposited on the aggregates as hydroxides (in-situ coating) (Fig. 1). Iron oxide-coated sand is a good adsorbent for several contaminants including chromium ${ }^{39,85}$, pathogens ${ }^{86,87}$ and phosphates ${ }^{88,89} \cdot \mathrm{Fe}^{0}$ oxidation also contributes to produce anoxic conditions which are favorable for the abiotic reductive transformation of several dissolved species including chlorinated compound ${ }^{38,90}$. Unlike sand and other inert aggregates, $\mathrm{MnO}_{2}$ is reactive and uses $\mathrm{Fe}^{2+}$ for its reductive dissolution (Eq. 3). Because the reaction occurs at the surface of $\mathrm{MnO}_{2}$ (Fig. 1), $\mathrm{Fe}^{0}$ passivation is delayed until the oxidative capacity of $\mathrm{MnO}_{2}$ is exhausted. Results presented herein have demonstrated these mechanisms excellently, while benefiting from the tracer nature of methylene blue (MB method $)^{30,79}$. In fact, mechanistic discussions are often complicated by the need to consider the redox reactivity of both $\mathrm{Fe}^{0}$ and $\mathrm{MnO}_{2}$ with the contaminant of concern ${ }^{72}$. In other words, one major output of this research is that the popular hypothesis to rationalize reductive transformations in $\mathrm{Fe}^{0} / \mathrm{H}_{2} \mathrm{O}$ systems is faulty ${ }^{91}$. The hypothesis that $\mathrm{Fe}^{0}$ is an electron donor for dissolved has been seriously challenged during the past 15 years, however, the questioned view is still prevailing ${ }^{11,36,59}$.

The stoichiometry of electrochemical reactions (similar to Eq. 2) has been routinely used to design $\mathrm{Fe}^{0}$ remediation systems ${ }^{92,93}$. The evidence that twice more $\mathrm{Fe}^{0}$ is needed to exchange the same number of electrons when reduction is induced by $\mathrm{Fe}^{2+}$ implies that the service life of $\mathrm{Fe}^{0}$-based systems has been wrongly estimated ${ }^{57}$. The statement is valid regardless of the approach used to estimate the efficiency of the system. However, the main problem has been the failure to properly consider the expansive nature of iron corrosion, which makes only hybrid systems viable in the long term ${ }^{14}$.

The importance of hybrid $\mathrm{Fe}^{0} / \mathrm{H}_{2} \mathrm{O}$ systems. The long history of $\mathrm{Fe}^{0}$ filtration systems teaches that only hybrid systems are sustainable. The Bischof filters, applied both for household and large-scale uses, contained a reactive zone made up of $25 \%$ sponge iron ( $\mathrm{vol} / \mathrm{vol}$ ) mixed with gravel ${ }^{41,94}$. The Multi-Soil-Layering of Wakatsuki et al. ${ }^{89}$ contained only $15 \% \mathrm{Fe}^{0}(\mathrm{w} / \mathrm{w})$ (iron fillings) mixed with $15 \% \mathrm{Fe}^{0}(\mathrm{w} / \mathrm{w})$ pelletized jute and balanced with zeolite (60\%). The phosphate filters of Erickson et al. ${ }^{95}$ contained only up to $5 \%$ steel wool balanced with sand. All these systems operated for more that 1 year without clogging. In the framework of subsurface permeable reactive barriers, O'Hannesin and Gillham ${ }^{31}$ tested a reactive wall containing $22 \% \mathrm{Fe}^{0}$ balanced with gravel and reported on good hydraulic properties in the long term. Other systems with $100 \% \mathrm{Fe}^{0}$ have failed because of loss of porosity coupled with the early development of preferential flow paths in the $\mathrm{Fe}^{0}$ permeable reactive barrier ${ }^{96}$. However, the availability of preferential flow paths was globally attributed to mineral precipitation (e.g. calcium carbonate, iron oxides, sulfide minerals). The key point is that iron oxides resulting from corrosion products are more abundant and universally present, and their generation should be reduced by "diluting" $\mathrm{Fe}^{0}$ with non-expansive aggregates like gravel or sand.

All systems containing a pure $\mathrm{Fe}^{0}$ layer $(100 \%)$ were reported to be efficient but not sustainable ${ }^{97-99}$. The most prominent example is probably the use of iron filings for selenium removal from agricultural drainage water by the Harza Process ${ }^{98,100}$. In 1985, Harza Engineering Co. tested a pilot-scale process using iron filings in flow-through beds. The testing was discontinued because the beds quickly cemented with precipitates ${ }^{100}$. The study concluded that the advantage of $\mathrm{Fe}^{0}$ filtration is to decrease Se concentration to very low concentrations. The mechanism of Se removal was further investigated and it was established that Se is not reduced by an electrochemical mechanism ${ }^{98}$. Furthermore, $\mathrm{Fe}^{0}$ filters were suggested as a polishing step following microbial treatments ${ }^{100}$. Despite this evidence, it is disappointing to observe that available works on Se removal in $\mathrm{Fe}^{0} /$ 
based systems have not built on existing knowledge as Se is still reported to be reduced by electrons from the metal body $y^{60,101-103}$. Following the state-of-the-art knowledge on the sustainability of $\mathrm{Fe}^{0}$ filtration, hybrid $\mathrm{Fe}^{0}$ systems should have been tested as stand-alone technology for Se removal. In essence, such work was independently conducted by Huang and his colleagues ${ }^{15,43,104,105}$ who developed and demonstrated the efficiency of a hybrid $\mathrm{Fe}^{0} / \mathrm{Fe}_{3} \mathrm{O}_{4}$ for the removal of several micro-pollutants, including $\mathrm{Mo}^{\mathrm{VI}}, \mathrm{NO}_{3}{ }^{-}$and $\mathrm{Se}^{\mathrm{VI}}$, and recently for the mitigation of pathogens (bacteria) from dairy manure. The fact that a hybrid system, initially developed for chemically reducible micro-pollutants is performing well for pathogens corroborate the idea that it suffices to sustain iron corrosion to achieve water treatment ${ }^{37,52-54,106}$. As discussed in the "Introduction", Huang et al..$^{43}$ have not convincingly demonstrated the specificity of their hybrid system $\left(\mathrm{Fe}^{0} / \mathrm{Fe}_{3} \mathrm{O}_{4}\right)$. This is particularly the case in a context where $\mathrm{Fe}^{0}$ /sand systems are already essentially more sustainable than pure $\mathrm{Fe}^{0}(100 \%)^{14,49}$. The present work also confirms previous results that any additive to $\mathrm{Fe}^{0}$ basically delay the availability of corrosion products under typical field conditions. The observed enhanced performance results from sustained iron corrosion in the whole system. The question then arises, what makes $\mathrm{MnO}_{2}$ a specific admixing aggregate for $\mathrm{Fe}^{0}$ filters?

The suitability of hybrid $\mathrm{Fe}^{0} / \mathrm{MnO}_{2}$ systems. The presentation until now has demonstrated that applying $\mathrm{Fe}^{0}$ for water treatment is promising as mixing $\mathrm{Fe}^{0}$ with other aggregates delays passivation or sustain treatment efficiency. Moreover, substantial experiences have been accumulated on the functionality of hybrid systems for water treatment ("The importance of hybrid $\mathrm{Fe}^{0} / \mathrm{H}_{2} \mathrm{O}$ systems"). The knowledge that $\mathrm{Fe}^{0}$ acts as generator of contaminant scavengers (and never as reducing agent) implies that adsorption and co-precipitation are the fundamental mechanisms of contaminant removal in $\mathrm{Fe}^{0} / \mathrm{H}_{2} \mathrm{O}$ systems. Hybrid systems tested as means to prevent iron passivation include amendment with granular activated carbon (GAC), magnetite $\left(\mathrm{Fe}_{3} \mathrm{O}_{4}\right)$, manganese oxides $\left(\mathrm{MnO}_{\mathrm{x}}\right)$, pyrite $\left(\mathrm{FeS}_{2}\right)$, and sand ${ }^{15}$. Among these aggregates, $\mathrm{MnO}_{\mathrm{x}}$ and $\mathrm{FeS}_{2}$ are the most chemically reactive ${ }^{36,71}$. Both aggregates induce a $\mathrm{pH}$ shift to more acidic values. However, because iron corrosion increases the $\mathrm{pH}$, it is possible to find the optimal $\mathrm{Fe}^{0} / \mathrm{FeS}_{2}$ and $/$ or $\mathrm{Fe}^{0} / \mathrm{MnO}_{2}$ ratio for case-specific water treatment. Therefore, long-term systematic testing with well-characterized materials is necessary.

Note that $\mathrm{Fe}^{0}$ is a generator of iron oxides, and adding $\mathrm{Mn}$ oxides $\left(\mathrm{MnO}_{\mathrm{x}}\right)$ to the system creates a very complex system, which is not new to geochemists, but which is yet to be investigated in the context of water treatment ${ }^{68,72}$. In fact, taken individually, the redox reactivity of these minerals plays important roles in the fate and transformation of many contaminants in natural environments ${ }^{59,61-64,70-72}$. Available works mostly investigate simple model systems with few contaminants ${ }^{68,72}$. To bridge the gap between simple model systems and complex environmental systems, a profound understanding of the redox reactivity of $\mathrm{Mn}$ - and Fe-oxides in complex model systems toward water decontamination is urgently needed. The effects of natural ligands $\left(\mathrm{Cl}^{-}, \mathrm{HCO}_{3}^{-}, \mathrm{PO}_{4}{ }^{3-}\right.$, $\mathrm{SO}_{4}{ }^{2-}$ ) and natural organic matter (NOM) on the redox reactivity of $\mathrm{Fe}^{0} / \mathrm{MnO}_{2}$ systems need to be investigated as well. Moreover, there is need to investigate the following: (i) fate of contaminants in $\mathrm{Fe}^{0}$ systems, and (ii) the safe disposal of spent $\mathrm{Fe}^{0}$ materials, including their use as filler material in novel construction materials, and the behavior of contaminants in such materials.

\section{Concluding remarks}

This study clearly delineates the important role of reactive $\mathrm{MnO}_{\mathrm{x}}$ minerals on the process of water treatment using $\mathrm{Fe}^{0}$-based systems. The presence of $\mathrm{MnO}_{\mathrm{x}}$ induces $\mathrm{Fe}^{2+}$ oxidation at the mineral surface, resulting in a significant delay of $\mathrm{Fe}^{0}$ passivation compared to that attained in $\mathrm{Fe}^{0}$ and $\mathrm{Fe}^{0}$ /sand systems. Being a natural mineral or a soil resource, its incorporation in $\mathrm{Fe}^{0}$ filters reinforces the frugality of this already demonstrated affordable system. It is expected that adding $\mathrm{MnO}_{\mathrm{x}}$ to $\mathrm{Fe}^{0} / \mathrm{H}_{2} \mathrm{O}$ will create geochemical dynamics in the system which would sustain iron corrosion and maintain the efficiency of system for water decontamination for the long term. This would make $\mathrm{Fe}^{0}$ filters a sustainable solution for decentralized safe drinking water provision and enable the realization of universal access to safe drinking water and even on a self-reliant manner. To bridge the existing knowledge gaps, the need for further research entailing long-term testing of $\mathrm{Fe}^{0}$ systems was highlighted.

Received: 15 March 2021; Accepted: 26 May 2021

Published online: 08 June 2021

\section{References}

1. Schumacher, E. F. Small is Beautiful: Economics as If People Mattered (Harper \& Row, 1973).

2. Howe, K. J., Hand, D. W., Crittenden, J. C., Trussell, R. R. \& Tchobanoglous, G. Principles of Water Treatment (Wiley, 2012).

3. Liu, P., Gernjak, W. \& Keller, J. Long-term performance of enhanced-zero valent iron for drinking water treatment: A lab-scale study. Chem. Eng. J. 315, 124-131 (2017).

4. Tepong-Tsindé, R., Ndé-Tchoupé, A. I., Noubactep, C., Nassi, A. \& Ruppert, H. Characterizing a newly designed steel-woolbased household filter for safe drinking water provision: Hydraulic conductivity and efficiency for pathogen removal. Processes 7, 966 (2019).

5. Nya, E. L. Access to drinking water and sanitation in Nde Division. Cameroon. PhD Dissertation, University of Yaoundé I. (2020).

6. Nya, E. L. \& Mougoué, B. Access to safe drinking water and sanitary risks in the town of Bangangté (West Region of Cameroon). Saudi J. Hum. Soc. Sci. https://doi.org/10.36348/sjhss.2020.v05i03.007 (2020).

7. Banerji, T. \& Chaudhari, S. A cost-effective technology for arsenic removal: Case study of zerovalent iron-based IIT Bombay arsenic filter in West Bengal. In Water and Sanitation in the New Millennium (eds Nath, K. \& Sharma, V.) (Springer, 2017).

8. Kearns, J. P., Bentley, M. J., Mokashi, P., Redmon, J. H. \& Levine, K. Underrepresented groups in WaSH-The overlooked role of chemical toxicants in water and health. J. Water Sanit. Hyg. Dev. 9, 786-793 (2019).

9. Hussam, A. \& Munir, A. K. M. A simple and effective arsenic filter based on composite iron matrix: Development and deployment studies for groundwater of Bangladesh. J. Environ. Sci. Health A 42, 1869-1878 (2007). 
10. Antia, D. D. J. Water treatment and desalination using the eco-materials $n-\mathrm{Fe}^{0}(\mathrm{ZVI}), \mathrm{n}-\mathrm{Fe}_{3} \mathrm{O}_{4}, \mathrm{n}-\mathrm{Fe}_{\mathrm{x}} \mathrm{O}_{\mathrm{y}} \mathrm{H}_{\mathrm{z}}\left[\mathrm{mH}_{2} \mathrm{O}\right]$, and $\mathrm{n}-\mathrm{Fe}_{\mathrm{x}}[\text { Cation }]_{\mathrm{n}} \mathrm{O}_{\mathrm{y}} \mathrm{H}_{\mathrm{z}}[\text { Anion }]_{\mathrm{m}}\left[\mathrm{rH}_{2} \mathrm{O}\right]$. In Handbook of Nanomaterials and Nanocomposites for Energy and Environmental Applications (eds Kharissova, O. V. et al.) (Springer Nature, 2020). https://doi.org/10.1007/978-3-030-11155-7_66-1.

11. Cao, V. et al. Tracing the scientific history of $\mathrm{Fe}^{0}$-based environmental remediation prior to the advent of permeable reactive barriers. Processes 8, 977 (2020).

12. Yang, $\mathrm{H}$. et al. Designing the next generation of $\mathrm{Fe}^{0}$-based filters for decentralized safe drinking water treatment. Processes $\mathbf{8}$, $745(2020)$.

13. Huang, Z., Cao, V., Nya, E. L., Gwenzi, W. \& Noubactep, C. Kanchan arsenic filters and the future of $\mathrm{Fe}^{0}$-based filtration systems for single household drinking water supply. Processes 9,58 (2021).

14. Domga, R., Togue-Kamga, F., Noubactep, C. \& Tchatchueng, J. B. Discussing porosity loss of $\mathrm{Fe}^{0}$ packed water filters at ground level. Chem. Eng. J. 263, 127-134 (2015).

15. Han, S., Huang, Y. \& Liu, Z. Bacterial indicator reduction in dairy manure using hybridzero-valent iron (h-ZVI) system. Environ. Sci. Pollut. Res. 26, 10790-10799 (2019).

16. Henderson, A. D. \& Demond, A. H. Long-term performance of zero-valent iron permeable reactive barriers: A critical review. Environ. Eng. Sci. 24, 401-423 (2007).

17. Bartzas, G. \& Komnitsas, K. Solid phase studies and geochemical modelling of low-cost permeable reactive barriers. J. Hazard Mater. 183, 301-308 (2010).

18. Li, L. \& Benson, C. H. Evaluation of five strategies to limit the impact of fouling in permeable reactive barriers. J. Hazard Mater. 181, 170-180 (2010).

19. Guan, X. et al. The limitations of applying zero-valent iron technology in contaminants sequestration and the corresponding countermeasures: The development in zero-valent iron technology in the last two decades (1994-2014). Water Res. 75, 224-248 (2015).

20. Gheju, M. \& Balcu, I. Sequential abatement of $\mathrm{Fe}^{\mathrm{II}}$ and $\mathrm{Cr}^{\mathrm{VI}}$ water pollution by use of walnut shell-based adsorbents. Processes 9, $218(2021)$.

21. Caré, S. et al. Modeling the permeability loss of metallic iron water filtration systems. Clean: Soil, Air, Water 41, 275-282 (2013).

22. Moraci, N., Lelo, D., Bilardi, S. \& Calabrò, P. S. Modelling long-term hydraulic conductivity behaviour of zero valent iron column tests for permeable reactive barrier design. Can. Geotech. J. 53, 946-961 (2016).

23. Li, J. et al. Characterization methods of zerovalent iron for water treatment and remediation. Water Res. 148, $70-85$ (2019).

24. Lufingo, M., Ndé-Tchoupé, A. I., Hu, R., Njau, K. N. \& Noubactep, C. A novel and facile method to characterize the suitability of metallic iron for water treatment. Water 11, 2465 (2019).

25. Romanoff, M. Underground Corrosion. United States Department of Commerce, National Bureau of Standards. Circular 579 (1957).

26. Melchers, R. E. \& Petersen, R. B. A reinterpretation of the Romanoff NBS data for corrosion of steels in soils. Corros. Eng. Sci. Technol. 53, 131-140 (2018).

27. Stefanonia, M., Zhanga, Z., Angsta, U. \& Elsener, B. The kinetic competition between transport and oxidation of ferrous ions governs precipitation of corrosion products in carbonated concrete. RILEM Tech. Lett. 3, 8-16 (2018).

28. Stefanoni, M., Angst, U. M. \& Elsener, B. Kinetics of electrochemical dissolution of metals in porous media. Nat. Mater. 18, 942-947 (2019).

29. Whitney, W. R. The corrosion of iron. J. Am. Chem. Soc. 25, 394-406 (1903).

30. Miyajima, K. \& Noubactep, C. Characterizing the impact of sand addition on the efficiency of granular iron for water treatment. Chem. Eng. J. 262, 891-896 (2015).

31. O'Hannesin, S. F. \& Gillham, R. W. Long-term performance of an in situ "iron wall" for remediation of VOCs. Ground Water 36, 164-170 (1998).

32. Phillips, D. H. et al. Ten year performance evaluation of a field-scale zero-valent iron permeable reactive barrier installed to remediate trichloroethene contaminated groundwater. Environ. Sci. Technol. 44, 3861-3869 (2010).

33. Wilkin, R. T. et al. Fifteen-year assessment of a permeable reactive barrier for treatment of chromate and trichloroethylene in groundwater. Sci. Tot. Environ. 468-469, 186-194 (2014).

34. Wilkin, R. T. et al. Geochemical and isotope study of trichloroethene degradation in a zero-valent iron permeable reactive barrier: A twenty-two-year performance evaluation. Environ. Sci. Technol. 53, 296-306 (2019).

35. Roh, Y., Lee, S. Y. \& Elless, M. P. Characterization of corrosion products in the permeable reactive barriers. Environ. Geol. 40, 184-194 (2000).

36. Hu, R., Cui, X., Xiao, M., Gwenzi, W. \& Noubactep, C. Characterizing the impact of pyrite addition on the efficiency of $\mathrm{Fe}^{0} / \mathrm{H}_{2} \mathrm{O}$ systems. Sci. Rep. 11, 2326 (2021).

37. Noubactep, C. Processes of contaminant removal in " $\mathrm{Fe}^{0}-\mathrm{H}_{2} \mathrm{O}$ " systems revisited. The importance of co-precipitation. Open Environ. Sci. 1, 9-13 (2007).

38. Jiao, Y. et al. Reductive dechlorination of carbon tetrachloride by zero-valent iron and related iron corrosion. Appl. Catal. B Environ. 91, 434-440 (2009).

39. Gheju, M. Hexavalent chromium reduction with zero-valent iron (ZVI) in aquatic systems. Water Air Soil Pollut. 222, 103-148 (2011).

40. Ghauch, A. Iron-based metallic systems: An excellent choice for sustainable water treatment. Freiberg Online Geosci. 32, 1-80 (2015).

41. Bischof, G. On the purification of water. Proc. R. Philos. Soc. Glasgow 8, 357-372 (1973).

42. Mackenzie, P. D., Horney, D. P. \& Sivavec, T. M. Mineral precipitation and porosity losses in granular iron columns. J. Hazard Mater. 68, 1-17 (1999).

43. Huang, Y. H., Tang, C. \& Zeng, H. Removing molybdate from water using a hybridized zero-valent iron/magnetite/Fe(II) treatment system. Chem. Eng. J. 200-202, 257-263 (2012).

44. Noubactep, C., Meinrath, G., Dietrich, P. \& Merkel, B. Mitigating uranium in groundwater: Prospects and limitations. Environ. Sci. Technol. 37, 4304-4308 (2003).

45. Noubactep, C., Btatkeu-K, B. D. \& Tchatchueng, J. B. Impact of $\mathrm{MnO}_{2}$ on the efficiency of metallic iron for the removal of dissolved metal. Chem. Eng. J. 178, 78-84 (2011).

46. Lipczynska-Kochany, E., Harms, S., Milburn, R., Sprah, G. \& Nadarajah, N. Degradation of carbon tetrachloride in the presence of iron and sulphur containing compounds. Chemosphere 29, 1477-1489 (1994).

47. Westerhoff, P. \& James, J. Nitrate removal in zero-valent iron packed columns. Water Res. 37, 1818-1830 (2003).

48. Bi, E., Devlin, J. F. \& Huang, B. Effects of mixing granular iron with sand on the kinetics of trichloroethylene reduction. Ground Water Monit. Remed. 29, 56-62 (2009).

49. Song, D. I., Kim, Y. H. \& Shin, W. S. A simple mathematical analysis on the effect of sand in Cr(VI) reduction using zero valent iron. Korean J. Chem. Eng. 22, 67-69 (2005).

50. Ndé-Tchoupé, A. I., Makota, S., Nassi, A., Hu, R. \& Noubactep, C. The suitability of pozzolan as admixing aggregate for $\mathrm{Fe}^{0}$-based filters. Water 10, 417 (2018).

51. Bigg, T. \& Judd, S. J. Zero-valent iron for water treatment. Environ. Technol. 21, 661-670 (2000). 
52. Furukawa, Y., Kim, J.-W., Watkins, J. \& Wilkin, R. T. Formation of ferrihydrite and associated iron corrosion products in permeable reactive barriers of zero-valent iron. Environ. Sci. Technol. 36, 5469-5475 (2002).

53. Purenović, M., Perović, J., Bojić, A., Andelković, T. \& Bojić, D. Cu and Cd removal from wastewater by a microalloyed aluminium composite. Environ. Chem. Lett. 2, 59-63 (2004).

54. Burghardt, D. \& Kassahun, A. Development of a reactive zone technology for simultaneous in situ immobilisation of radium and uranium. Environ. Geol. 49, 314-320 (2005).

55. Yoon, I. H., Kim, K. W., Bang, S. \& Kim, M. G. Reduction and adsorption mechanisms of selenate by zero-valent iron and related iron corrosion. Appl. Catal. B Environ. 104, 185-192 (2011).

56. Xu, J. et al. Reactivity, selectivity, and long-term performance of sulfidized nanoscale zerovalent iron with different properties. Environ. Sci. Technol. 53, 5936-5945 (2019).

57. Cao, V., Ndé-Tchoupé, A. I., Hu, R., Gwenzi, W. \& Noubactep, C. Discussing the mechanism of contaminant removal in $\mathrm{Fe}^{0} /$ $\mathrm{H}_{2} \mathrm{O}$ systems: The burden of a poor literature review. Chemosphere 280, 130614 (2021).

58. Zhang, L., Zhang, Y., Gao, X. \& Xu, C. Insights on the effects of $\mathrm{pH}$ and $\mathrm{Fe}(\mathrm{II})$ regeneration during the chromate sequestration by sulfidated zero-valent iron. Chem. Eng. J. 378, 122115 (2019).

59. Alyoussef, G. Characterizing the impact of contact time in investigating processes in $\mathrm{Fe}^{0} / \mathrm{H}_{2} \mathrm{O}$ systems. Freiberg Online Geosci. 58, 1-80 (2021)

60. Wang, X., Zhang, X., Wang, Z., Xu, C. \& Tratnyek, P. G. Advances in metal(loid) oxyanion removal by zerovalent iron: Kinetics, pathways, and mechanisms. Chemosphere https://doi.org/10.1016/j.chemosphere.2021.130766 (2021).

61. Appelo, C. A. J. \& Postma, D. Variable dispersivity in a column experiment containing $\mathrm{MnO}_{2}$ and $\mathrm{FeOOH}$-coated sand. J. Cont. Hydrol. 40, 95-106 (1999).

62. Appelo, C. A. J. \& Postma, D. A consistent model for surface complexation on birnessite $\left(\mathrm{MnO}_{2}\right)$ and its application to a column experiment. Geochim. Cosmochim. Acta 63, 3039-3048 (1999).

63. Post, J. E. Manganese oxide minerals: Crystal structures and economic and environmental significance. Proc. Natl. Acad. Sci. 96, 3447-3454 (1999).

64. Tebo, B. M. et al. Biogenic manganese oxides: Properties and mechanisms of formation. Annu. Rev. Earth Planet Sci. 32, 287-328 (2004).

65. Vodyanitskii, Y. N. Mineralogy and geochemistry of manganese: A review of publications. Eurasian Soil Sci. 42, 1170-1178 (2009).

66. Penrose, R. A. F. The chemical relation of iron and manganese in sedimentary rocks. J. Geol. 1, 356-370 (1893).

67. Fischel, M. H. H., Fischel, J. S., Lafferty, B. J. \& Sparks, D. L. The influence of environmental conditions on kinetics of arsenite oxidation by manganese-oxides. Geochem. Trans. 16, 15 (2015).

68. Huang, J. \& Zhang, H. Redox reactions of iron and manganese oxides in complex systems. Front. Environ. Sci. Eng. 14, 76 (2020).

69. Lewis, A. E. Review of metal sulphide precipitation. Hydrometallurgy 104, 222-234 (2010).

70. Cao, V., Alyoussef, G., Gatcha-Bandjun, N., Gwenzi, W. \& Noubactep, C. The suitability of methylene blue discoloration (MB method) to investigate the $\mathrm{Fe}^{0} / \mathrm{MnO}_{2}$ system. Processes 9, 548 (2021).

71. Cao, V., Alyoussef, G., Gatcha-Bandjun, N., Gwenzi, W. \& Noubactep, C. Characterizing the impact of $\mathrm{MnO}_{2}$ addition on the efficiency of $\mathrm{Fe}^{0} / \mathrm{H}_{2} \mathrm{O}$ systems. Sci. Rep. https://doi.org/10.1038/s41598-021-89318-w (2021).

72. Michel, M. M. et al. Mineral materials coated with and consisting of $\mathrm{MnO}_{\mathrm{x}}-$ Characteristics and application of filter media for groundwater treatment: A review. Materials 13, 2232 (2020).

73. Shindo, H. \& Huang, P. M. Catalytic effects of manganese(IV), iron(III), aluminum, and silicon oxides on the formation of phenolic polymers. Soil Sci. Soc. Am. J. 48, 927-934 (1984).

74. Sparrow, L. A. \& Uren, N. C. Manganese oxidation and reduction in soils: Effects of temperature, water potential, $\mathrm{pH}$ and their interactions. Soil Res. 52, 483-494 (2014).

75. Ye, Z., Giraudon, J. M., De Geyter, N., Morent, R. \& Lamonier, J. F. The design of MnOx based catalyst in post-plasma catalysis configuration for toluene abatement. Catalysts 8, 91 (2018).

76. Varlikli, C. et al. Adsorption of dyes on Sahara desert sand. J. Hazard Mater. 170, 27-34 (2009).

77. Mitchell, G., Poole, P. \& Segrove, H. D. Adsorption of methylene blue by high-silica sands. Nature 176, 1025-1026 (1955).

78. Kurth, A. M. Discoloration of methylene blue by elemental iron-Influence of the shaking intensity. Bachelor thesis, Universität Göttingen, 45 (2008).

79. Miyajima, K. Optimizing the design of metallic iron filters for water treatment. Freiberg Online Geosci. 32, 1-60 (2012).

80. Brenner, S. Sequences and consequences. Philos. Trans. R. Soc. B 365, 207-212 (2010).

81. Lavine, B. K., Auslander, G. \& Ritter, J. Polarographic studies of zero valent iron as a reductant for remediation of nitroaromatics in the environment. Microchem. J. 70, 69-83 (2001).

82. Noubactep, C., Schöner, A. \& Meinrath, G. Mechanism of uranium (VI) fixation by elemental iron. J. Hazard Mater. 132, 202-212 (2006).

83. Gatcha-Bandjun, N., Noubactep, C. \& Loura-Mbenguela, B. Mitigation of contamination in effluents by metallic iron: The role of iron corrosion products. Environ. Technol. Innov. 8, 71-83 (2017).

84. Touomo-Wouafo, M. et al. Electrochemical monitoring of heavy metals removal from aqueous solutions by aged metallic iron. Competitive effects of cations $\mathrm{Zn}^{2+}, \mathrm{Pb}^{2+}$ and $\mathrm{Cd}^{2+}$. Monatsh. Chem. 151, 1511-1523 (2020).

85. Powell, M. R., Puls, W. R., Hightower, K. S. \& Sebatini, A. D. coupled iron corrosion and chromate reduction: Mechanisms for subsurface remediation. Environ. Sci. Technol. 29, 1913-1922 (1995).

86. Bojic, A. et al. The inactivation of Escherichia coli by microalloyed aluminium based composite. Facta Universitatis 2, 115-124 (2001).

87. You, Y., Han, J., Chiu, P. C. \& Jin, Y. Removal and inactivation of waterborne viruses using zerovalent iron. Environ. Sci. Technol. 39, 9263-9269 (2005).

88. James, B. R., Rabenhorst, M. C. \& Frigon, G. A. Phosphorus sorption by peat and sand amended with iron oxides or steel wool. Water Environ. Res. 64, 699-705 (1992).

89. Wakatsuki, T., Esumi, H. \& Omura, S. High performance and N, P removable on-site domestic wastewater treatment system by multi-soil-layering method. Water Sci. Technol. 27, 31-40 (1993).

90. Khudenko, B. M. Feasibility evaluation of a novel method for destruction of organics. Water Sci. Technol. 23, 1873-1881 (1991).

91. Matheson, L. J. \& Tratnyek, P. G. Reductive dehalogenation of chlorinated methanes by iron metal. Environ. Sci. Technol. 28, 2045-2053 (1994).

92. Sarr, D. Zero-valent-iron permeable reactive barriers-How long will they last?. Remediation 11, 1-18 (2001).

93. Obiri-Nyarko, F., Grajales-Mesa, S. J. \& Malina, G. An overview of permeable reactive barriers for in situ sustainable groundwater remediation. Chemosphere 111, 243-259 (2014).

94. Devonshire, E. The purification of water by means of metallic iron. J. Frankl. Inst. 129, 449-461 (1890).

95. Erickson, A. J., Gulliver, J. S. \& Weiss, P. T. Enhanced sand filtration for storm water phosphorus removal. J. Environ. Eng. 133, 485-497 (2007).

96. Morrison, S. J., Mushovic, P. S. \& Niesen, P. L. Early breakthrough of molybdenum and uranium in a permeable reactive barrier. Environ. Sci. Technol. 40, 2018-2024 (2006).

97. Murphy, A. P. Removal of selenate from water by chemical reduction. Ind. Eng. Chem. Res. 27, 181-191 (1988). 
98. Anderson, M. A. Fundamental aspects of selenium removal by Harza process. Rep San Joaquin Valley Drainage Program, US Dep Interior, Sacramento (1989).

99. Hussam, A. Contending with a development disaster: Sono filters remove arsenic from well water in Bangladesh. Innovations 4, 89-102 (2009).

100. Frankenberger, W. T. Jr. et al. Advanced treatment technologies in the remediation of seleniferous drainage waters and sediments. Irrig. Drain. Syst. 18, 19-41 (2004).

101. Liang, L. et al. Efficient selenate removal by zero-valent iron in the presence of weak magnetic field. Sep. Purif. Technol. 156, 1064-1072 (2015).

102. Liang, L. et al. Kinetics of selenite reduction by zero-valent iron. Desalin. Water Treat. 53, 2540-2548 (2015).

103. Qin, H. et al. Unexpected effect of buffer solution on removal of selenite and selenate by zerovalent iron. Chem. Eng. J. 334, 296-304 (2018).

104. Huang, Y. H., Peddi, P. K., Zeng, H., Tang, C.-L. \& Teng, X. Pilot-scale demonstration of the hybrid zero-valent iron process for treating flue-gas-desulfurization wastewater: Part I. Water Sci. Technol. 67, 16-23 (2013).

105. Huang, Y. H., Peddi, P. K., Zeng, H., Tang, C.-L. \& Teng, X. Pilot-scale demonstration of the hybrid zero-valent iron process for treating flue-gas-desulfurization wastewater: Part II. Water Sci. Technol. 67, 239-246 (2013).

106. Noubactep, C. A critical review on the mechanism of contaminant removal in $\mathrm{Fe}^{0}-\mathrm{H}_{2} \mathrm{O}$ systems. Environ. Technol. 29, 909-920 (2008).

\title{
Acknowledgements
}

For providing the iron material investigated in this study the authors would like to express their gratitude to iPutec $\mathrm{GmbH}$ (Rheinfelden, Germany). The natural $\mathrm{MnO}_{2}$-mineral was provided by the Department of Geology of the Technical University Bergakademie Freiberg/Germany (Mineralsammlung). Mohammad Azizur Rahman (Technovative Solutions, Manchester Science Park, Manchester/UK) is thanked for technical support. The manuscript was improved by the insightful comments of anonymous reviewers from Scientific Reports. We acknowledge support by the German Research Foundation and the Open Access Publication Funds of the Göttingen University.

\section{Author contributions}

G.A., V.C., N.G.-B. and C.N. conceived the presented idea and developed the theory. G.A. carried out the experiments. C.N. supervised this work. W.G. supervised the redaction of the first draft by V.C. and N.G.-B. All authors discussed the results and contributed to the final manuscript.

\section{Funding}

Open Access funding enabled and organized by Projekt DEAL.

\section{Competing interests}

The authors declare no competing interests.

\section{Additional information}

Correspondence and requests for materials should be addressed to C.N.

Reprints and permissions information is available at www.nature.com/reprints.

Publisher's note Springer Nature remains neutral with regard to jurisdictional claims in published maps and institutional affiliations.

\begin{abstract}
Open Access This article is licensed under a Creative Commons Attribution 4.0 International License, which permits use, sharing, adaptation, distribution and reproduction in any medium or format, as long as you give appropriate credit to the original author(s) and the source, provide a link to the Creative Commons licence, and indicate if changes were made. The images or other third party material in this article are included in the article's Creative Commons licence, unless indicated otherwise in a credit line to the material. If material is not included in the article's Creative Commons licence and your intended use is not permitted by statutory regulation or exceeds the permitted use, you will need to obtain permission directly from the copyright holder. To view a copy of this licence, visit http://creativecommons.org/licenses/by/4.0/.
\end{abstract}

(c) The Author(s) 2021 